$\underline{\text { Supplementary Materials }}$

\title{
Potent Estrogen Receptor Ligands Based on Bisphenols with a Globular Hydrophobic Core
}

\author{
Yasuyuki Endo, ${ }^{*, \dagger}$ Tomohiro Yoshimi,${ }^{\dagger}$ Kiminori Ohta, ${ }^{\dagger}$ Tomoharu Suzuki ${ }^{\ddagger}$ \\ and Shigeru Ohta \\ Faculty of Pharmaceutical Sciences, Tohoku Pharmaceutical University, \\ 4-4-1, Komatsushima, Aoba-ku, Sendai 981-8558, Japan \\ Graduate School of Medical Sciences, Hiroshima University, \\ 1-2-3 Kasumi, Minami-ku, Hiroshima 734-8551, Japan
}


Comparison of structures for compounds with carborane core $(\mathbf{6}, \mathbf{7}, \mathbf{8})$ and compounds with hydrocarbone cores $(9,10,11,12)$<smiles>Oc1ccc(C2C3C4C(c5ccc(O)cc5)C5C2C3C45)cc1</smiles>
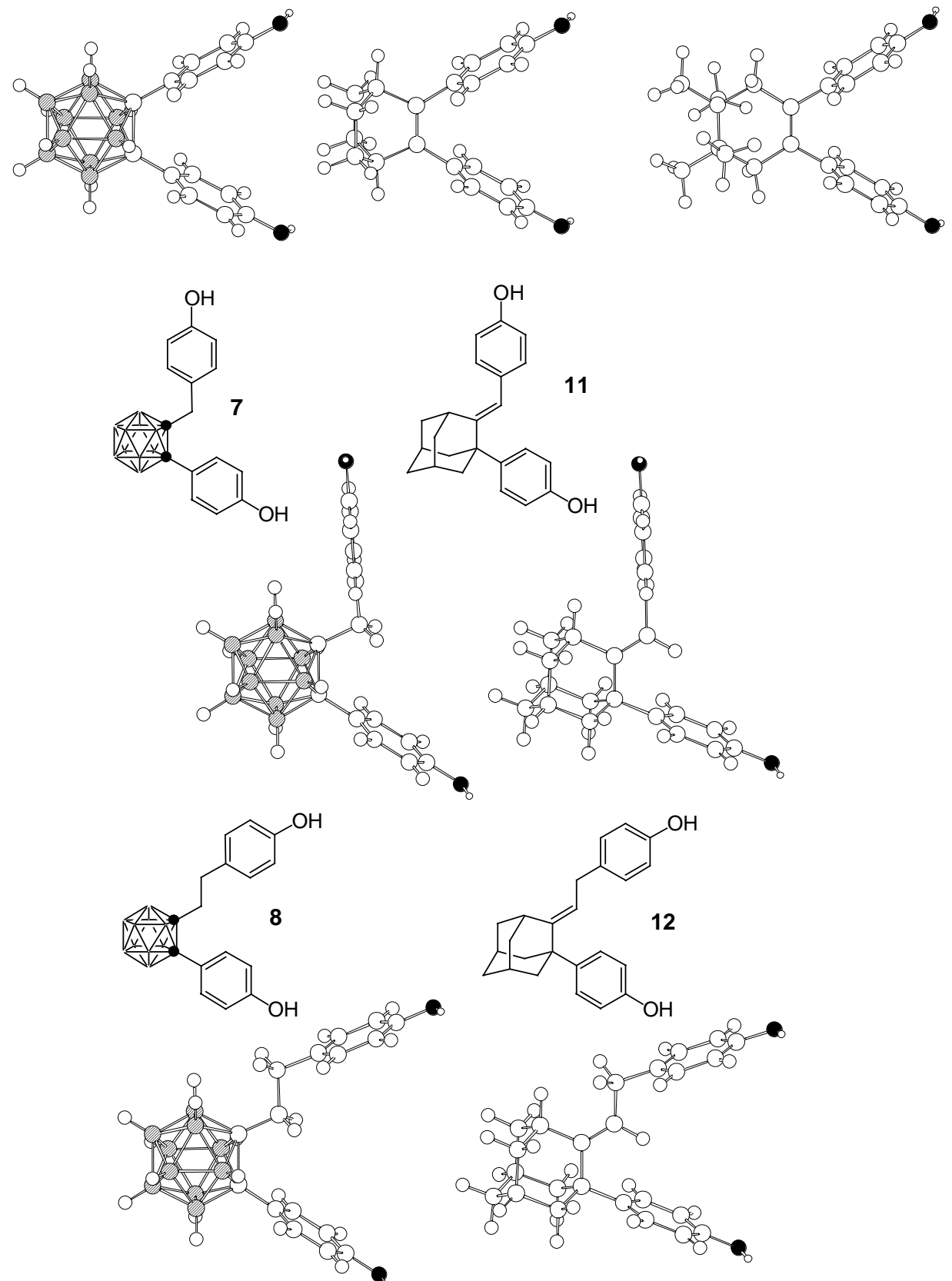
Synthesis, spectral data for compounds 7-12 and experimental procedures of biological $\underline{\text { evaluations }}$

1-\{4-[(2-Methoxyethoxy)methoxy]phenyl\}-1,2-dicarba-closo-dodecaborane (14). A solution of decaborane (14) (4.65 g, $38.0 \mathrm{mmol})$, 1-ethynyl-4-[(2-methoxyethoxy)methoxy]benzene $(7.84 \mathrm{~g}, 38.0 \mathrm{mmol})$ and acetonitrile $(15 \mathrm{ml})$ in dry benzene $(150 \mathrm{ml})$ was refluxed under an argon atmosphere for $45 \mathrm{~h}$. After removal of the solvent under reduced pressure, the residue was purified by column chromatography on silica gel (eluent: hexane/ethyl acetate, 2:1) to afford 14 as a colorless solid (4.50 g, 37\%). Colorless plates (AcOEt-hexane); mp 46-47 $\square$. ${ }^{1} \mathrm{H}-\mathrm{NMR}\left(400 \mathrm{MHz}, \mathrm{CDCl}_{3}\right.$ ) $\delta:$ 1.50-3.20 (brm, 10H), 3.37 (s, 3H), 3.54 (m, 2H), 3.80 (m, 2H), 3.88 (brs, 1H), 5.26 (s, 2H), 6.98 (d, $J=8.8 \mathrm{~Hz}, 2 \mathrm{H}), 7.40$ (d, $J=9.0 \mathrm{~Hz}, 2 \mathrm{H})$. HRMS Calcd for $\mathrm{C}_{12} \mathrm{H}_{24}{ }^{10} \mathrm{~B}_{2}{ }^{11} \mathrm{~B}_{8} \mathrm{O}_{3}: 324.2729$, Found: 324.2725 .

1-[4-(tert-Butyldimethylsiloxy)benzyl]-2-\{4-[(2-methoxyethoxy)methoxy]phenyl\}-1,2-dicarba -closo-dodecaborane (15). To a solution of $14(2.18 \mathrm{~g}, 6.73 \mathrm{mmol})$ in benzene/ $\mathrm{Et}_{2} \mathrm{O}(2: 1,30$ $\mathrm{ml})$ was added dropwise a $1.6 \mathrm{M}$ solution of $n$-BuLi in hexane $(5.05 \mathrm{~mL}, 8.08 \mathrm{mmol})$ at $0{ }^{\circ} \mathrm{C}$ under Ar. The mixture was stirred at room temperature for $30 \mathrm{~min}$. The solution was cooled at $0^{\circ} \mathrm{C}$ and 4-(tert-butyldimethylsiloxy)benzyl bromide $(3.04 \mathrm{~g}, 10.1 \mathrm{mmol})$ in $\mathrm{Et}_{2} \mathrm{O}(5 \mathrm{ml})$ was added dropwise, then the mixture was refluxed for $18 \mathrm{~h}$. The reaction was quenched with water and the mixture was extracted with $\mathrm{Et}_{2} \mathrm{O}$. The organic layer was washed with brine, dried over $\mathrm{Na}_{2} \mathrm{SO}_{4}$, and concentrated. Purification by silica gel flash column chromatography (eluent: hexane/AcOEt, 4:1) gave $\mathbf{1 5}(1.31 \mathrm{~g}, 36 \%)$ as a viscous liquid. The starting material 14 was recovered in 58\% yield. ${ }^{1} \mathrm{H}-\mathrm{NMR}\left(400 \mathrm{MHz} \mathrm{CDCl}_{3}\right) \delta: 0.18(\mathrm{~s}, 6 \mathrm{H}), 0.96(\mathrm{~s}, 9 \mathrm{H})$, 1.50-3.10 (brm, 10H), $3.00(\mathrm{~s}, 2 \mathrm{H}), 3.37$ (s, 3H), $3.56(\mathrm{~m}, 2 \mathrm{H}), 3.84(\mathrm{~m}, 2 \mathrm{H}), 5.32(\mathrm{~s}, 2 \mathrm{H})$, $6.70(\mathrm{~s}, 4 \mathrm{H}), 7.08(\mathrm{~d}, J=9.0 \mathrm{~Hz}, 2 \mathrm{H}), 7.59(\mathrm{~d}, J=9.0 \mathrm{~Hz}, 2 \mathrm{H})$. HRMS Calcd for $\mathrm{C}_{25} \mathrm{H}_{44}{ }^{10} \mathrm{~B}_{2}{ }^{11} \mathrm{~B}_{8} \mathrm{O}_{4}$ Si: 544.4012, Found: 544.4022. 
1-(4-Hydroxybenzyl)-2-(4-hydroxyphenyl)-1,2-dicarba-closo-dodecaborane (7: BE380).

A solution of $15(153 \mathrm{mg}, 0.281 \mathrm{mmol})$ in methanol $(5 \mathrm{ml})$ was refluxed with $0.2 \mathrm{ml}$ of conc. hydrochloric acid for $30 \mathrm{~min}$. After addition of water, the mixture was extracted with $\mathrm{Et}_{2} \mathrm{O}$. The organic layer was washed with brine, dried over $\mathrm{Na}_{2} \mathrm{SO}_{4}$, and concentrated. Purification by silica gel flash column chromatography (eluent: hexane/AcOEt, 1:1) gave 7 (96 mg, quant.) as a colorless solid. Colorless prisms $\left(\mathrm{CH}_{2} \mathrm{Cl}_{2}\right.$-hexane); mp 176-178 ${ }^{\circ} \mathrm{C} .{ }^{1} \mathrm{H}-\mathrm{NMR}(400$ $\left.\mathrm{MHz}, \mathrm{CDCl}_{3}\right) \delta: 1.40-3.10(\mathrm{brm}, 10 \mathrm{H}), 3.02(\mathrm{~s}, 2 \mathrm{H}), 4.70(\mathrm{br}, 1 \mathrm{H}), 5.12$ (br, 1H), 6.69 (d, $J=$ $9.0 \mathrm{~Hz}, 2 \mathrm{H}), 6.72(\mathrm{~d}, J=8.8 \mathrm{~Hz}, 2 \mathrm{H}), 6.87(\mathrm{~d}, J=8.8 \mathrm{~Hz}, 2 \mathrm{H}), 7.56(\mathrm{~d}, J=9.0 \mathrm{~Hz}, 2 \mathrm{H})$. HRMS Calcd for $\mathrm{C}_{15} \mathrm{H}_{22}{ }^{10} \mathrm{~B}_{2}{ }^{11} \mathrm{~B}_{8} \mathrm{O}_{2}$ : 342.2623, Found: 342.2600. Anal. Calcd for $\mathrm{C}_{15} \mathrm{H}_{22} \mathrm{~B}_{10} \mathrm{O}_{2}$ : C, 52.61; H, 6.48. Found: C, 52.65; H, 6.49.

1-[4-(tert-Butyldimethylsiloxy)phenethyl]-2-\{4-[(2-methoxyethoxy)methoxy]phenyl\}-1,2-

dicarba-closo-dodecaborane (16). Compound 16 was prepared from 14 by the same method as that used for preparation of $\mathbf{1 5}$, with 4-(tert-butyldimethylsiloxy)phenethyl bromide. Purification by silica gel flash column chromatography (eluent: hexane/AcOEt, 4:1) gave 16 (23\%). The starting material 14 was recovered in $75 \%$ yield. ${ }^{1} \mathrm{H}-\mathrm{NMR}\left(400 \mathrm{MHz}, \mathrm{CDCl}_{3}\right) \delta$ : 0.14 (s, 6H), 0.94 (s, 9H), 1.40-3.00 (brm, 10H), 2.03 (m, 2H), 2.58 (m, 2H), 3.35 (s, 3H), $3.54(\mathrm{~m}, 2 \mathrm{H}), 3.81(\mathrm{~m}, 2 \mathrm{H}), 5.29(\mathrm{~s}, 2 \mathrm{H}), 6.64(\mathrm{~d}, J=8.4 \mathrm{~Hz}, 2 \mathrm{H}), 6.73(\mathrm{~d}, J=8.4 \mathrm{~Hz}, 2 \mathrm{H})$, $7.03(\mathrm{~d}, J=9.2 \mathrm{~Hz}, 2 \mathrm{H}), 7.55(\mathrm{~d}, J=8.8 \mathrm{~Hz}, 2 \mathrm{H})$. HRMS Calcd for $\mathrm{C}_{26} \mathrm{H}_{46}{ }^{10} \mathrm{~B}_{2}{ }^{11} \mathrm{~B}_{8} \mathrm{O}_{4} \mathrm{Si}$ : 558.4168, Found: 558.4164.

\section{1-(4-Hydroxyphenethyl)-2-\{4-[(2-methoxyethoxy)methoxy]phenyl\}-1,2-dicarba-closo-}

dodecaborane $(8, B E 381)$. Compound 8 was prepared from 16 by the same method as that used for preparation of 7. Purification by silica gel flash column chromatography (eluent: hexane/AcOEt, 1:1) gave 8 (99 \%). Colorless prisms $\left(\mathrm{CH}_{2} \mathrm{Cl}_{2}\right.$-hexane); mp 173-175 $\square$. ${ }^{1} \mathrm{H}-\mathrm{NMR}\left(400 \mathrm{MHz}, \mathrm{CDCl}_{3}\right.$ ) $\delta: 1.40-3.00$ (brm, 10H), 2.01 (m, 2H), 2.58 (m, 2H), 4.58 (brs, 1H), 5.10 (brs, 1H), $6.66(\mathrm{~d}, J=8.6 \mathrm{~Hz}, 2 \mathrm{H}), 6.75$ (d, $J=8.6 \mathrm{~Hz}, 2 \mathrm{H}), 6.81$ (d, $J=9.0 \mathrm{~Hz}$, 
2H), $7.51(\mathrm{~d}, J=9.0 \mathrm{~Hz}, 2 \mathrm{H})$. HRMS Calcd for $\mathrm{C}_{16} \mathrm{H}_{24}{ }^{10} \mathrm{~B}_{2}{ }^{11} \mathrm{~B}_{8} \mathrm{O}_{2}$ : 356.2779, Found: 356.2810. Anal. Calcd for $\mathrm{C}_{16} \mathrm{H}_{24} \mathrm{~B}_{10} \mathrm{O}_{2}$ : C, 53.91; H, 6.79. Found: $\mathrm{C}, 53.69 ; \mathrm{H}, 6.76$.

(Z)-2,3-Bis(4-methoxyphenyl)but-2-ene-1,4-diol (18). To a solution of 3,4-bis(4-methoxyphenyl)-5H-furan-2-one ${ }^{15}$ (17, $\left.7.22 \mathrm{~g}, 24.4 \mathrm{mmol}\right)$ in THF (250 ml) was added diisobutylaluminum hydride (0.95 $\mathrm{M}$ in hexane, $100 \mathrm{ml}, 95.0 \mathrm{mmol})$. The mixture was stirred for $30 \mathrm{~min}$ at $0^{\circ} \mathrm{C}$, then for $2 \mathrm{~h}$ at room temperature under an argon atmosphere. The mixture was poured into $10 \%$ aqueous hydrochloric acid and extracted with AcOEt. The organic layer was washed with brine, dried over $\mathrm{MgSO}_{4}$, and concentrated. Purification by silica gel flash column chromatography (eluent: hexane/AcOEt, 1:1 to AcOEt) gave 18 (4.90 $\mathrm{g}, 46 \%)$ as a colorless viscous liquid. ${ }^{1} \mathrm{H}-\mathrm{NMR}\left(270 \mathrm{MHz}, \mathrm{CDCl}_{3}\right) \delta: 3.73(\mathrm{~s}, 6 \mathrm{H}), 4.62$ (s, 4H), $6.68(\mathrm{~d}, J=8.9 \mathrm{~Hz}, 4 \mathrm{H}), 6.99(\mathrm{~d}, J=8.9 \mathrm{~Hz}, 4 \mathrm{H})$. LRMS: $m / z, 300\left(\mathrm{M}^{+}\right)$.

Tetraethyl 4,5-bis(4-methoxyphenyl)cyclohex-4-ene-1,1,2,2-tetracarboxylate (19). To a solution of $18(4.90 \mathrm{~g}, 16.3 \mathrm{mmol})$ in $\mathrm{Et}_{2} \mathrm{O}(100 \mathrm{ml})$ was added pyridine $(0.5 \mathrm{ml})$ and $\mathrm{PBr}_{3}$ (4.41 g, $16.3 \mathrm{mmol})$. The mixture was refluxed for $90 \mathrm{~min}$. The mixture was poured into ice water and extracted with $\mathrm{Et}_{2} \mathrm{O}$. The organic layer was washed with brine, dried over $\mathrm{MgSO}_{4}$, and concentrated to afford a $3: 4$ mixture of $E-, \quad Z$ 1,4-dibromo-2,3-bis(4-methoxyphenyl)but-2-ene. Z-form: ${ }^{1} \mathrm{H}-\mathrm{NMR}\left(270 \mathrm{MHz}, \mathrm{CDCl}_{3}\right) \delta$ : $3.74(\mathrm{~s}, 6 \mathrm{H}), 4.50(\mathrm{~s}, 4 \mathrm{H}), 6.69(\mathrm{~d}, J=8.9 \mathrm{~Hz}, 4 \mathrm{H}), 7.00(\mathrm{~d}, J=8.9 \mathrm{~Hz}, 4 \mathrm{H}) . E$-form:

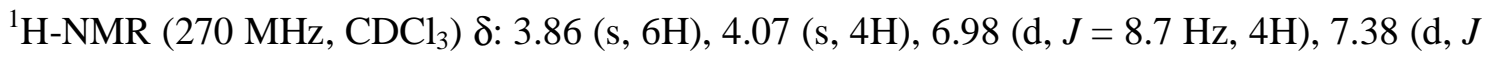
$=8.9 \mathrm{~Hz}, 4 \mathrm{H})$. The bromide was used for subsequent reaction without further purification, because isomerization of the $Z$-form to the undesired $E$-form occurs during purification. Sodium hydride (60\% in oil, $1.29 \mathrm{~g}, 32.3 \mathrm{mmol}$ ) was washed with $n$-hexane, dried under reduced pressure and suspended in $90 \mathrm{ml}$ of THF under an Ar atmosphere. A solution of 4.66 $\mathrm{g}(14.6 \mathrm{mmol})$ of tetraethylethane-1,1,2,2-tetracarboxylate and was added to the above solution at $0^{\circ} \mathrm{C}$. the mixture was stirred for $15 \mathrm{~min}$, then a solution of $E$-, Z- mixture of the 
bromide (5.65 g, $13.3 \mathrm{mmol})$ in THF (60 ml) was added. The resulting solution was refluxed for $14 \mathrm{~h}$, then poured into water, and the whole was extracted with AcOEt. The organic phase was washed with brine, dried over $\mathrm{MgSO}_{4}$ and concentrated. Purification by column chromatography on silica gel (eluent: $n$-hexane/ethyl acetate 3:1) afforded $3.42 \mathrm{~g}$ (39 \%, 2 steps) of 19 as a pale yellow viscous liquid. ${ }^{1} \mathrm{H}-\mathrm{NMR}\left(270 \mathrm{MHz}, \mathrm{CDCl}_{3}\right) \delta: 1.29$ (t, $J=7.1$ $\mathrm{Hz}, 12 \mathrm{H}), 3.18$ (s, 4H), $3.72(\mathrm{~s}, 6 \mathrm{H}), 4.26$ (q, $J=7.1 \mathrm{~Hz}, 8 \mathrm{H}), 6.65$ (d, $J=8.9 \mathrm{~Hz}, 4 \mathrm{H}), 6.89$ $(\mathrm{d}, J=8.7 \mathrm{~Hz}, 4 \mathrm{H})$. LRMS: $m / z 582\left(\mathrm{M}^{+}\right)$.

4,4,5,5-Tetrakis(bromomethyl)-1,2-bis(4-methoxyphenyl)cyclohex-1-ene (20). To a solution of $19(2.47 \mathrm{~g}, 4.24 \mathrm{mmol})$ in THF (100 mL) was added portionwise $\mathrm{LiAlH}_{4}(644 \mathrm{mg}, 17.0$ $\mathrm{mmol})$. The mixture was refluxed for $20 \mathrm{~h}$ under an Ar atmosphere, then poured into 10\% aqueous hydrochloric acid, and the whole was extracted with AcOEt. The organic phase was washed with brine, dried over $\mathrm{MgSO}_{4}$ and concentrated. The resulting tetrol was dissolved in pyridine $(16 \mathrm{~mL})$ and this solution was added to methanesulfonyl chloride (2.91 g, 25.4 mmol) at $-15^{\circ} \mathrm{C}$. The mixture was stirred for $24 \mathrm{~h}$ at room temperature under an $\mathrm{Ar}$ atmosphere, poured into $10 \%$ aqueous hydrochloric acid and extracted with AcOEt. The organic phase was washed with brine, dried over $\mathrm{MgSO}_{4}$ and concentrated. The mesylate was dissolved in 2-ethoxyethanol $(60 \mathrm{~mL})$ and $\mathrm{LiBr}(4.42 \mathrm{~g}, 50.9 \mathrm{mmol})$ was added at room temperature. The mixture was heated to reflux for $66 \mathrm{~h}$. Water was added, and the whole was extracted with $\mathrm{Et}_{2} \mathrm{O}$. The organic phase was washed with brine, dried over $\mathrm{MgSO}_{4}$ and concentrated. Purification by silica gel flash column chromatography (eluent: hexane/AcOEt, 10:1) gave 20 (838 mg, 30\%) as a pale yellow viscous liquid. ${ }^{1} \mathrm{H}-\mathrm{NMR}\left(270 \mathrm{MHz}, \mathrm{CDCl}_{3}\right) \delta$ : $2.72(\mathrm{~s}, 4 \mathrm{H}), 3.73(\mathrm{~s}, 6 \mathrm{H}), 3.82(\mathrm{~d}, J=10.6 \mathrm{~Hz}, 4 \mathrm{H}), 4.24(\mathrm{~d}, J=10.9 \mathrm{~Hz}, 4 \mathrm{H}), 6.68(\mathrm{~d}, J=$ $8.7 \mathrm{~Hz}, 4 \mathrm{H}), 6.90(\mathrm{~d}, J=8.9 \mathrm{~Hz}, 4 \mathrm{H})$.

1,2-Bis(4-hydroxyphenyl)-4,4,5,5-tetramethylcyclohex-1-ene (9, BE1054). To a solution of 20 (319 mg, $0.479 \mathrm{mmol})$ in HMPT (10 ml) was added $\mathrm{NaBH}_{4}(145 \mathrm{mg}, 3.83 \mathrm{mmol})$, and the 
mixture was heated at $80^{\circ} \mathrm{C}$ for $45 \mathrm{~h}$ under an Ar atmosphere. The mixture was poured into water and extracted with AcOEt. The organic phase was washed with brine, dried over $\mathrm{MgSO}_{4}$ and concentrated. Purification by silica gel flash column chromatography (eluent: hexane/AcOEt, 10:1) gave 1,2-bis(4-methoxyphenyl)-4,4,5,5-tetramethylcyclohex-1-ene (116

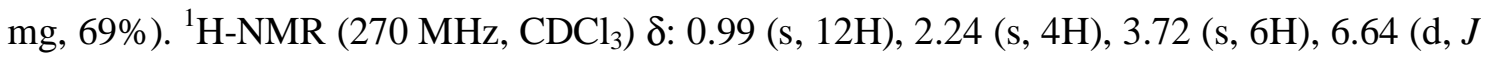
$=8.9 \mathrm{~Hz}, 4 \mathrm{H}), 6.89(\mathrm{~d}, J=8.7 \mathrm{~Hz}, 4 \mathrm{H})$. To a solution of the product described above $(116 \mathrm{mg}$, $0.331 \mathrm{mmol})$ in $\mathrm{CH}_{2} \mathrm{Cl}_{2}(1 \mathrm{ml})$ was added dropwise a $1 \mathrm{M}$ solution of $\mathrm{BBr}_{3}$ in $\mathrm{CH}_{2} \mathrm{Cl}_{2} \quad(0.83$ $\mathrm{ml}$ ) at $-78^{\circ} \mathrm{C}$. The mixture was stirred at room temperature for $12 \mathrm{~h}$, then poured into ice water, and extracted with AcOEt. The organic layer was washed with brine, dried over $\mathrm{MgSO}_{4}$, and concentrated. Purification by silica gel column chromatography (eluent: hexane/AcOEt, 2:1) gave 9 (107 mg, 99\%). 9: colorless powder $\left(\mathrm{CH}_{2} \mathrm{Cl}_{2}\right.$-hexane); mp 70-71 ${ }^{\circ} \mathrm{C} .{ }^{1} \mathrm{H}-\mathrm{NMR}\left(270 \mathrm{MHz}, \mathrm{CD}_{3} \mathrm{OD}\right) \delta: 1.00$ (s, 12H), $2.20(\mathrm{~s}, 4 \mathrm{H}), 6.50(\mathrm{~d}, J=8.7 \mathrm{~Hz}$, $4 \mathrm{H}), 6.75(\mathrm{~d}, J=8.6 \mathrm{~Hz}, 4 \mathrm{H}) .{ }^{13} \mathrm{C}-\mathrm{NMR}\left(67.5 \mathrm{MHz}, \mathrm{CD}_{3} \mathrm{OD}\right) \delta: 24.2,35.6,46.9,115.3$, 131.0, 133.5, 136.3, 155.9. HRMS Calcd for $\mathrm{C}_{22} \mathrm{H}_{26} \mathrm{O}_{2}: 322.1933$, Found 322.1905. Anal. Calcd for $\mathrm{C}_{22} \mathrm{H}_{26} \mathrm{O}_{2} \square 1 / 4 \mathrm{H}_{2} \mathrm{O}$ : C, 80.82; H, 8.17. Found C, 80.54; H, 8.26.

2,3-Bis(4-methoxyphenyl)bicyclo[2.2.2]oct-2-ene (22). A mixture of 2,3-dibromobicyclo[2.2.2] oct-2-ene $^{17}(\mathbf{2 1}, 330 \mathrm{mg}, 1.24 \mathrm{mmol})$, 4-methoxyphenylboronic acid (471 mg, $3.10 \mathrm{mmol}), \mathrm{Pd}\left(\mathrm{PPh}_{3}\right)_{4}(143 \mathrm{mg}, 0.124 \mathrm{mmol})$ and $\mathrm{Na}_{2} \mathrm{CO}_{3}$ (1.97 g, 18.6 $\mathrm{mmol}$ ) in $170 \mathrm{ml}$ of toluene/EtOH/water (5:5:2) was refluxed for $24 \mathrm{~h}$ under an $\mathrm{Ar}$ atmosphere. After removal of the solvent under reduced pressure, the mixture was added to water and extracted with AcOEt. The organic layer was washed with brine, dried over $\mathrm{MgSO}_{4}$, and concentrated. Purification by silica gel column chromatography (eluent: hexane/AcOEt,

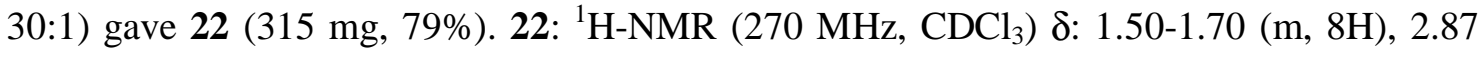
(brs, 2H), $3.76(\mathrm{~s}, 6 \mathrm{H}), 6.71(\mathrm{~d}, J=8.7 \mathrm{~Hz}, 4 \mathrm{H}), 7.02$ (d, $J=8.9 \mathrm{~Hz}, 4 \mathrm{H})$. LRMS: $m / z 320$ $\left(\mathrm{M}^{+}\right)$. 
2,3-Bis(4-hydroxyphenyl)bicyclo[2.2.2] loct-2-ene (10: BE1060) To a solution of 22 (310 mg, $0.967 \mathrm{mmol})$ in $\mathrm{CH}_{2} \mathrm{Cl}_{2}(3 \mathrm{ml})$ was added dropwise a $1 \mathrm{M}$ solution of $\mathrm{BBr}_{3}$ in $\mathrm{CH}_{2} \mathrm{Cl}_{2} \quad$ (2.43 $\mathrm{ml})$ at $-78{ }^{\circ} \mathrm{C}$. The mixture was stirred at room temperature for $16 \mathrm{~h}$, then poured into ice water, and extracted with AcOEt. The organic layer was washed with brine, dried over $\mathrm{MgSO}_{4}$, and concentrated. Purification by silica gel column chromatography (eluent: hexane/AcOEt, 4:1) gave a $9: 4$ mixture of $\mathbf{1 0}$ and 6,7-bis(4-hydroxyphenyl)bicyclo[3.2.1]oct-6-ene (245 $\mathrm{mg}, \quad 87 \%)$. Purification by recrystallization (three times) afforded 10. Data for the rearranged isomer: ${ }^{1} \mathrm{H}-\mathrm{NMR}$ (270 $\left.\mathrm{MHz}, \mathrm{CD}_{3} \mathrm{OD}\right) \delta:$ 1.50-1.80 (m, 7H), $2.25(\mathrm{~m}, 1 \mathrm{H}), 2.80(\mathrm{~m}, 2 \mathrm{H}), 6.62(\mathrm{~d}, J=8.7 \mathrm{~Hz}, 4 \mathrm{H})$, $7.06(\mathrm{~d}, J=8.7 \mathrm{~Hz}, 4 \mathrm{H}) .{ }^{13} \mathrm{C}-\mathrm{NMR}\left(150 \mathrm{MHz}, \mathrm{CD}_{3} \mathrm{OD}\right) \delta: 20.4,26.7,45.1,47.4,115.9$, 130.2, 132.1, 137.8, 156.8. 10: colorless prisms (AcOEt-hexane); mp 157-159 ${ }^{\circ} \mathrm{C} .{ }^{1} \mathrm{H}-\mathrm{NMR}$ $\left(270 \mathrm{MHz}, \mathrm{CD}_{3} \mathrm{OD}\right) \delta: 1.50-1.75(\mathrm{~m}, 8 \mathrm{H}), 2.81(\mathrm{~m}, 2 \mathrm{H}), 6.56(\mathrm{~d}, J=8.7 \mathrm{~Hz}, 4 \mathrm{H}), 6.88(\mathrm{~d}, J=$ $8.7 \mathrm{~Hz}, 4 \mathrm{H}) .{ }^{13} \mathrm{C}-\mathrm{NMR}\left(150 \mathrm{MHz}, \mathrm{CD}_{3} \mathrm{OD}\right) \delta: 27.3,38.8,115.7,130.6,134.0,139.8,156.5$. HRMS Calcd for $\mathrm{C}_{20} \mathrm{H}_{20} \mathrm{O}_{2}$ : 292.1463, Found 292.1435. Anal. Calcd for $\mathrm{C}_{22} \mathrm{H}_{26} \mathrm{O}_{2} \square 1 / 2 \mathrm{H}_{2} \mathrm{O}$ : C, 79.71; H, 7.02. Found C, 79.74; H, 7.33.

1-(4-Methoxyphenyl)-2-methyleneadamantane (26). To a stirred solution of methyltriphenylphosphonium bromide $(6.97 \mathrm{~g}, 19.5 \mathrm{mmol})$ in THF $(15 \mathrm{~mL})$, sodium bis(trimethylsilyl)amide $(1.0 \mathrm{M}$ in THF, $19.5 \mathrm{~mL}, 19.5 \mathrm{mmol})$ was added at $-60^{\circ} \mathrm{C}$ under an Ar atmosphere, and the solution was stirred for $1 \mathrm{~h}$. A solution of 1-(4-methoxyphenyl)adamantan-2-one ${ }^{18}(\mathbf{2 4}, 2.00 \mathrm{~g}, 7.80 \mathrm{mmol})$ in THF (40 mL) was added to the solution, and the mixture was stirred for $2 \mathrm{~h}$ at room temperature. It was then diluted with hexane, and filtered though Celite. The filtrate was concentrated and chromatographed on silica gel (eluent: hexane/AcOEt, 20:1) to give 26 (1.98 g, quant.). ${ }^{1} \mathrm{H}-\mathrm{NMR}$ (270 MHz, $\left.\mathrm{CDCl}_{3}\right) \delta: 1.75-2.41(\mathrm{~m}, 12 \mathrm{H}), 2.64(\mathrm{~m}, 1 \mathrm{H}), 3.81(\mathrm{~s}, 3 \mathrm{H}), 3.84(\mathrm{~d}, J=2.0 \mathrm{~Hz}, 1 \mathrm{H}), 4.59(\mathrm{~d}, J$ $=2.0 \mathrm{~Hz}, 1 \mathrm{H}), 6.88(\mathrm{~d}, J=9.0 \mathrm{~Hz}, 2 \mathrm{H}), 7.27(\mathrm{~d}, J=9.0 \mathrm{~Hz}, 2 \mathrm{H})$.

(E)-2-(4-Methoxybenzylidene)-1-(4-methoxyphenyl)adamantane (27). To a solution of 26 
(136 mg, $0.535 \mathrm{mmol})$ and 4-iodoanisole $(250 \mathrm{mg}, 1.07 \mathrm{mmol})$ in DMF (6 mL), was added $\mathrm{Pd}(\mathrm{OAc})_{2}(8 \mathrm{mg}, 0.036 \mathrm{mmol})$, triphenylphosphine $(19 \mathrm{mg}, 0.072 \mathrm{mmol})$ and $\mathrm{Ag}_{2} \mathrm{CO}_{3}(295$ $\mathrm{mg}, 1.07 \mathrm{mmol}$ ) at room temperature. The mixture was stirred for $72 \mathrm{~h}$ at $80^{\circ} \mathrm{C}$, then poured into water and extracted with $\mathrm{Et}_{2} \mathrm{O}$. The organic layer was washed with brine, dried over $\mathrm{MgSO}_{4}$, and concentrated. Purification of the residue by silica gel column chromatography (eluent: hexane/AcOEt, 30:1) gave 27 (134 mg, 70\%). ${ }^{1} \mathrm{H}-\mathrm{NMR}\left(270 \mathrm{MHz}, \mathrm{CDCl}_{3}\right) \delta$ : 1.80-2.45 (m, 12H), $3.24(\mathrm{~m}, 1 \mathrm{H}), 3.76(\mathrm{~s}, 3 \mathrm{H}), 3.82(\mathrm{~s}, 3 \mathrm{H}), 5.42(\mathrm{~s}, 1 \mathrm{H}), 6.78(\mathrm{~d}, J=8.7 \mathrm{~Hz}$, 2H), $6.90(\mathrm{~d}, J=8.9 \mathrm{~Hz}, 2 \mathrm{H}), 6.96(\mathrm{~d}, J=8.3 \mathrm{~Hz}, 2 \mathrm{H}), 7.33(\mathrm{~d}, J=9.1 \mathrm{~Hz}, 2 \mathrm{H})$.

(E)-2-(4-Hydroxybenzylidene)-1-(4-hydroxyphenyl)adamantane (11: BE1080). A mixture of 27 (130 mg, 0.361 mmol) and EtSNa (152 mg, $1.80 \mathrm{mmol})$ in DMF (5 mL) was refluxed for 3 $\mathrm{h}$ under an Ar atmosphere. The mixture was poured into water and extracted with AcOEt. The organic layer was washed with brine, dried over $\mathrm{MgSO}_{4}$, and concentrated. Purification of the residue by silica gel column chromatography (eluent: hexane/AcOEt, 2:1) afforded 11 (81 mg, 68\%). colorless prisms (AcOEt-hexane); mp 230-231 ${ }^{\circ} \mathrm{C} .{ }^{1} \mathrm{H}-\mathrm{NMR}(270 \mathrm{MHz}$, DMSO- $\left.d_{6}\right) \delta: 1.79-2.36(\mathrm{~m}, 12 \mathrm{H}), 3.16(\mathrm{~m}, 1 \mathrm{H}), 5.24(\mathrm{~s}, 1 \mathrm{H}), 6.62(\mathrm{~d}, J=8.2 \mathrm{~Hz}, 2 \mathrm{H}), 6.73$ (d, $J=8.6 \mathrm{~Hz}, 2 \mathrm{H}), 6.76(\mathrm{~d}, J=8.2 \mathrm{~Hz}, 2 \mathrm{H}), 7.15$ (d, $J=8.4 \mathrm{~Hz}, 2 \mathrm{H}), 9.19$ (s, 1H), 9.23 (s, 1H). ${ }^{13} \mathrm{C}-\mathrm{NMR}\left(67.5 \mathrm{MHz}, \mathrm{CD}_{3} \mathrm{OD}\right) \delta: 30.6,34.0,37.5,40.1,45.4,46.0,115.5,115.6,121.3$, 128.9, 130.5, 131.2, 139.1, 153.3, 156.1, 156.2. HRMS Calcd for $\mathrm{C}_{23} \mathrm{H}_{24} \mathrm{O}_{2}$ : 332.1776, Found 332.1739. Anal. Calcd for $\mathrm{C}_{23} \mathrm{H}_{24} \mathrm{O}_{2} \square 1 / 10 \mathrm{H}_{2} \mathrm{O}$ : C, 82.65; H, 7.30. Found C, 82.50; H, 7.26.

(Z)-1-(4-Methoxyphenyl)-2-[2-(4-methoxyphenyl)ethylidene]adamantane (25). To a stirred solution of 4-methoxyphenethyltriphenylphosphonium bromide $(2.37 \mathrm{~g}, 4.97 \mathrm{mmol})$ in $\mathrm{Et}_{2} \mathrm{O}$ $(10 \mathrm{ml}), n$-BuLi $(1.59 \mathrm{M}$ in hexane, $3.13 \mathrm{ml}, 4.97 \mathrm{mmol})$ was added at $0^{\circ} \mathrm{C}$ under an $\mathrm{Ar}$ atmosphere, and the mixture was stirred for $2.5 \mathrm{~h}$. A solution of $24^{18}$ (769 $\mathrm{mg}, 3.00 \mathrm{mmol}$ ) in THF $(5 \mathrm{~mL})$ was added to the solution, and the mixture was stirred for $44 \mathrm{~h}$ at $50^{\circ} \mathrm{C}$. The mixture was diluted with hexane, and filtered though Celite. The filtrate was concentrated 
and chromatographed on silica gel (eluent: hexane/AcOEt, 20:1) to give a mixture of Z-26 and its $E$-isomer (380 mg, 34\%). Purification of the mixture by recrystallization from hexane gave 26 (235mg, 21\%) 26: colorless needles (hexane); mp 132-134 $\square$. ${ }^{1} \mathrm{H}-\mathrm{NMR}$ (400 MHz, $\left.\mathrm{CDCl}_{3}\right) \delta: 1.72-2.18(\mathrm{~m}, 10 \mathrm{H}), 2.15(\mathrm{~d}, J=7.3 \mathrm{~Hz}, 2 \mathrm{H}), 2.39-2.44(\mathrm{~m}, 3 \mathrm{H}), 3.74(\mathrm{~s}, 3 \mathrm{H}), 3.78$ (s, 3H), $5.13(\mathrm{t}, J=7.3 \mathrm{~Hz}, 1 \mathrm{H}), 6.72(\mathrm{~d}, J=8.8 \mathrm{~Hz}, 2 \mathrm{H}), 6.83(\mathrm{~d}, J=9.0 \mathrm{~Hz}, 4 \mathrm{H}), 7.34(\mathrm{~d}, J$ $=9.0 \mathrm{~Hz}, 2 \mathrm{H})$. HRMS Calcd for $\mathrm{C}_{26} \mathrm{H}_{30} \mathrm{O}_{2}: 374.2246$, Found 374.2268.

(E)-1-(4-Hydroxyphenyl)-2-[2-(4-hydroxyphenyl)ethylidene]adamantane (12: BE1081). To a solution of 26 (38 mg, $0.10 \mathrm{mmol})$ in $\mathrm{CH}_{2} \mathrm{Cl}_{2}(1 \mathrm{ml})$ was added dropwise a $1 \mathrm{M}$ solution of $\mathrm{BBr}_{3}$ in $\mathrm{CH}_{2} \mathrm{Cl}_{2}(0.83 \mathrm{ml})$ at $-78^{\circ} \mathrm{C}$. The mixture was stirred at room temperature for $15 \mathrm{~h}$, then poured into ice water, and extracted with AcOEt. The organic layer was washed with brine, dried over $\mathrm{Na}_{2} \mathrm{SO}_{4}$, and concentrated. Purification by silica gel column chromatography (eluent: hexane/AcOEt, 3:1) gave 12 (35 mg, quant.). 12: colorless prisms $\left(\mathrm{CHCl}_{3}\right)$; mp 184-186 ${ }^{\circ} \mathrm{C} .{ }^{1} \mathrm{H}-\mathrm{NMR}\left(400 \mathrm{MHz}, \mathrm{CDCl}_{3}\right) \delta: 1.75-2.33(\mathrm{~m}, 12 \mathrm{H}), 3.07(\mathrm{~m}, 1 \mathrm{H})$, $3.19(\mathrm{~d}, J=7.5 \mathrm{~Hz}, 2 \mathrm{H}), 4.49-4.55(\mathrm{br}, 2 \mathrm{H}), 4.55(\mathrm{t}, J=7.5 \mathrm{~Hz}, 1 \mathrm{H}), 6.69(\mathrm{~d}, J=8.4 \mathrm{~Hz}, 2 \mathrm{H})$, $6.76(\mathrm{~d}, J=8.8 \mathrm{~Hz}, 2 \mathrm{H}), 6.91(\mathrm{~d}, J=8.6 \mathrm{~Hz}, 2 \mathrm{H}), 7.19(\mathrm{~d}, J=9.0 \mathrm{~Hz}, 2 \mathrm{H}) .{ }^{13} \mathrm{C}-\mathrm{NMR}(67.5$ $\left.\mathrm{MHz}, \mathrm{CD}_{3} \mathrm{OD}\right) \delta: 30.6,33.0,33.8,37.5,39.9,45.3,45.9,115.4,115.9,119.9,128.8,129.8$, 133.9, 139.2, 148.5, 151.4, 155.9. HRMS Calcd for $\mathrm{C}_{24} \mathrm{H}_{26} \mathrm{O}_{2}: 346.1933$, Found 346.1952. Anal. Calcd for $\mathrm{C}_{24} \mathrm{H}_{26} \mathrm{O}_{2}$ : C, 83.20; H, 7.56. Found C, 82.93; H, 7.79.

\section{Estrogen receptor $\alpha$ ligand binding assay}

The ligand binding activity of estrogen receptor $\alpha(\mathrm{ER} \alpha)$ was determined by the nitrocellulose filter binding assay method. $\operatorname{ER} \alpha(0.5 \mu \mathrm{g} / \mathrm{tube}$, PanVera Co. Ltd.) was diluted with a binding assay buffer (20 mM Tris- $\mathrm{HCl}$ pH 8.0, 0.3 M NaCl, $1 \mathrm{mM}$ EDTA pH 8.0, 10 $\mathrm{mM}$ 2-mercaptoethanol, $0.2 \mathrm{mM}$ phenylmethylsulfonyl fluoride) and incubated with $4 \mathrm{nM}$ $\left[6,7-{ }^{3} \mathrm{H}\right] 17 \beta$-estradiol in the presence or absence of an unlabeled competitor at $4^{\circ} \mathrm{C}$ for $16 \mathrm{~h}$. The incubation mixture was absorbed by suction onto a nitrocellulose membrane that had 
been soaked in binding assay buffer. The membrane was washed twice with buffer $(20 \mathrm{mM}$ Tris- $\mathrm{HCl} \mathrm{pH} 8.0,0.3 \mathrm{M} \mathrm{NaCl}$ ) and then with $25 \%$ ethanol in distilled water. Radioactivity that remained on the membrane was measured in Atomlight (NEN) by using a liquid scintillation counter.

\section{Transfection and luciferase assays}

Human breast cancer cell-line MCF-7 cells were maintained in DMEM (Sigma Chemical Co.) containing penicillin and streptomycin with $5 \%$ fetal bovine serum (FBS; Life Technologies, Rockville, MD). ERE-luciferase reporter assay using MCF-7 cells was performed according to the previously reported method. Briefly, transient transfections in MCF-7 cells were performed using Transfast ${ }^{\mathrm{TM}}$ (Promega Co., Madison, WI), according to the manufacturer's protocol. Transfections were done in 96-well plates at 8000 cells/well with $0.1 \mu \mathrm{g}$ of $\mathrm{p}(\mathrm{ERE})_{3}$-SV40-luc and $0.3 \mathrm{ng}$ of phRL/CMV (Promega Co.) as an internal standard. Twenty-four hours after addition of the sample, the assay was performed with a Dual Luciferase assay kit ${ }^{\mathrm{TM}}$ (Promega Co.). For the assay of anti-estrogens, the inhibitory effect of test compounds on the estrogenic activity of E2 at the concentration of $1 \times 10^{-10} \mathrm{M}$ was examined. 